\title{
30 cintised
}

\section{ROLAND BARTHES, ADORÁVEL: DISSEMINAÇÕES DE UMA VOZ DE AUTOR}

\author{
Maria Clara da Silva Ramos Carneiro' \\ Lauren Silva Nascimento ${ }^{2}$
}

RESUMO: Em seus cursos e textos, Roland Barthes descortinava a "cena da escritura": a partir de uma seleção de textos apresentava a forma como determinadas figuras, palavras e vocabulários se atualizavam a cada texto, a cada contexto. Conhecido como o crítico que matou o Autor, Barthes também se inscreve como personagem de uma narrativa intelectual fascinante: nos últimos anos de vida, seu luto público pela morte da mãe e a disseminação de elementos de si em textos e aulas reverberaram como a escrita de um romance real, um romance perdido ou escondido que se confunde com seu pensamento crítico da literatura.

PALAVRAS-CHAVE: Roland Barthes, autor, corpo, voz.

\section{ROLAND BARTHES, ADORABLE: DISSEMINATIONS OF AN AUTHOR'S VOICE}

ABSTRACT: In his courses and texts, Roland Barthes unveiled the "scene of the writing": from a selection of texts, he presented how some figures, words and vocabularies were updated in each text, each context. Known as the critic who killed the Author, Barthes inscribed himself as a character of a fascinating intellectual narrative: in his last years of life, his public mourning for the death of his mother and the dissemination of a self among his writings and courses reverberated as the writing of a real novel, a lost or hidden novel, mixed up with his reasoning on literary criticism.

KEYWORDS: Roland Barthes, author, body, voice.

\section{Introdução}

"L'amour est plus chair que ça" (Décio Pignatari em De Panteros)

"É ele inteiro que desenho (uma silhueta, uma forma, uma aparência?) Ou apenas uma parte desse corpo? [...] De todos os relevos do corpo tenho vontade de dizer que são adoráveis. Adorável quer dizer: esté é meu desejo, tanto que único: 'É isso! É exatamento

\footnotetext{
${ }^{1}$ Professora adjunta do Departamento de Línguas Estrangeiras Modernas (UFSM). Mestre em Letras Neolatinas (UFRJ), Doutora em Ciências da Literatura (UFRJ), líder do grupo de pesquisa "Oficinas de escrita, histórias em quadrinhos e tradução: teoria da literatura e práticas literárias". E-mail: maria.c.carneiro@ufsm.br.

2 Mestranda em Teoria Literária (UFSM). Bolsista PROBIC/FAPERGS (agosto de 2020 a junho de 2021) e atual bolsista FIPE-CAL-UFSM pelo projeto de pesquisa "Estudos de semiologia: noções de estilo, autoria e jogo", no seio do grupo liderado pela Profa. Maria Clara S. R. Carneiro. E-mail: nascimento.lauren@gmail.com.
} 


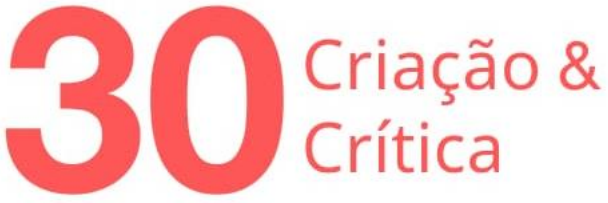

isso (que amo)!'

(Roland Barthes em Fragmentos de um discurso amoroso)

Roland Barthes foi um crítico amoroso: não apenas seus Fragmentos de um discurso amoroso (2011b) abriram literalmente o espaço para a sofreguidão do apaixonado, mas havia, em seus textos e cursos uma escolha transparente e enfatizada de ensinar ou escrever a partir de um desejo. Um discurso amoroso plus chair que qualquer outra coisa: convidava seus leitores e alunos a perceberem a materialidade do texto, o corpo desse texto. Também foi um dos críticos que mais escreveu sobre o lugar do leitor , deslocando a sacralização de um Autor para o espaço em que ele se atualiza: a leitura. Dessa forma, posicionou o sujeito (corpo e desejo) no lugar da objetividade pura, pois "Mais valem os logros da subjetividade do que as imposturas da objetividade. Mais vale o Imaginário do Sujeito do que a censura" (BARTHES, 2005a, p. 4).

A escritura - entendida aqui como a linguagem literária que determinado escritor desenvolve (BARTHES, 1974) -, ele observava, é uma área que vai desde a língua compartilhada pelo escritor em determinada sociedade ao estilo pessoal de um autor, nascidos de seu corpo e da história desse corpo (BARTHES, 1974, p. 122-123); porém, as "forças de liberdade" proporcionadas pela literatura independeriam desse sujeito criador. A escritura, parricida, contradiz aquele que escreve e o Autor, já morto, não teria qualquer controle sobre sua Obra: a atualização desse Texto e seu Autor, que mencionamos, é feita por outros sujeitos, outros corpos que os leem. O Autor, portanto, é uma rede de signos inscrita por um corpo, na forma de um Texto, cuja persistência no tempo advém pela relação que entretém com outros corpos pela via de sua inscrição. Desejos intermediados pelo Texto, que é capaz de provocar um desejo de escritura (e também de inscrição) naquele que o lê, também um desejo de sobrevivência na escritura. Uma relação sempre erótica, em que o sedutor também convoca quem ele seduz a alcançar esse poder cativante de escrever/seduzir: inspira amadores.

Enquanto descortinava essa dimensão erótica da literatura, Barthes também experimentava com sua própria escritura e personalidade, inscrevendo-se como personagem de uma narrativa intelectual fascinante. Uma audiência cativa o seguia: alunos, colegas, leitores, enquanto ele mesclava elementos pessoais a discussões sobre a literatura, sobretudo em seus últimos anos de vida, após a morte de sua mãe. Como observa Giordano, essa relação entre a escritura e o íntimo não era, porém, novidade em seus textos:

Em "Notas sobre André Gide e seu Diário", de 1942, o jovem Barthes não duvida em afirmar a continuidade entre escrita íntima e obra de arte, quando as confissões se autonomizam com respeito ao exercício espiritual que as desperta "graças ao prazer produzido por lê-las”. (GIORDANO, 2017, p. 147) 


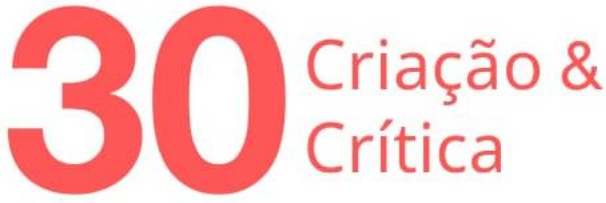

Em seus últimos livros publicados em vida, porém, há uma ênfase em um eu que escrevo, e um eu que escrevo um romance. Seu último curso, "A preparação do romance", era apresentado a partir de uma vontade pessoal de escrever um verdadeiro Romance. A partir da observação de alguns de seus textos e aulas, abordaremos de que forma a escrita desse Romance - ou o mistério em torno da escrita de um Romance - também trouxe à tona um encantamento em torno de um Barthes Autor, que se desdobra em uma figura pública "fascinante", cuja Obra crítica permite também se olhar como literatura. O presente texto é um discurso amoroso: acompanharemos a disseminação do corpo de Barthes por seus textos e cursos, para tentar avançar algumas palavras para além do adjetivo "adorável" que sua obra inspira.

\section{O Romance amador}

No último curso lecionado por Barthes, o Romance - em maiúsculas, no sentido de um arquétipo de romance - foi seu grande objeto de estudo, contudo Roland Barthes por Roland Barthes, Fragmentos de um discurso amoroso e $A$ câmara clara, publicados originalmente em 1975, 1977 e 1980, respectivamente, já flertavam com uma escrita romanesca. Como ele avisa no início do primeiro livro uma autobiografia em que mistura a primeira e a terceira pessoas do singular ao falar de si mesmo -, com sua própria letra manuscrita,

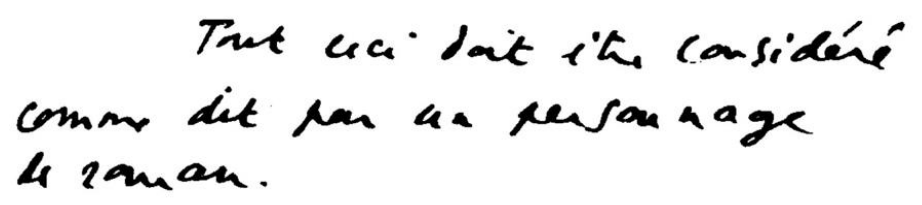

Figura 1 "Tudo isto deve ser considerado como dito por uma personagem de romance" (BARTHES, 2003, p. 11)

Algumas imagens também aparecem nesse prefácio ou prólogo: a foto de sua mãe, um desenho seu, a frase acima, elementos que remetem ao corpo desse autor. Ele nos permite vislumbrar uma memória real - uma História, cujo documento são as fotografias da mãe (o noema, tal como ele descreveria mais tarde, em $A$ câmara clara, do "isso foi") e o corpo em que essa memória se inscrevia - a materialidade do sujeito que escreve, pela impressão desse corpo sobre o papel (a letra manuscrita). A inserção desses biografemas, termo que ele mesmo cunhou para apontar fragmentos de um real em um texto de ficção, também aparecem em Fragmentos de um discurso amoroso e $A$ câmara clara. Por exemplo, nos Fragmentos (2011), ele intercala as falas do apaixonado à primeira pessoa do singular, coincidindo o eu que escreve e o eu apaixonado; em $A$ câmara clara 


\section{Criação \&}

(2009), referências bastante subjetivas em torno do imaginário e da fotografia se entrelaçam à narrativa do sujeito que busca a Mãe, recém-morta, em fotos da família.

Além da escrita romanesca, e do desejo do Romance expresso no curso supracitado, publicações póstumas como Incidentes (2004) e apontamentos de aulas reunidos em uma pasta em que se lia "Vita Nova" (que se supõe também o esboço de um livro) permitiriam inferir que ele já estaria escrevendo esse Romance, sempre em maiúscula.

Há muitas evidências (ou sintomas) da fantasia barthesiana de escrever um romance, ou uma tentativa de abandono do gênero ensaístico em prol de uma nova via literária. Porém, o ensaio barthesiano já estava repleto de elementos textuais que se aproximam de uma escritura, como a criação de novos significados para termos comuns, certa deformação da linguagem, com neologismos, etimologismos; i.e.: a exploração de recursos que criam um jogo textual que faz, de seu próprio texto, uma obra também plural. Um ensaio romanesco, ou um romance na forma de um ensaio?

Barthes recorre com frequência a um "eu" generalizante, esse "eu estou escrevendo um romance" que se confunde com o enunciador da aula, durante seus cursos:

[... ] Posso ter o desejo tenaz de escrever um romance (daí o título genérico: Preparação do romance) e constatar, depois, que não consigo fazê-lo, pela simples razão de que eu não sei mentir (não eu não quero, mas eu não sei); isso não quer dizer que eu sei dizer a Verdade; o que está fora dos meus limites é a invenção da Mentira, a Mentira luxuriosa, a Mentira que produz espuma: a Fabulação, a Mitomania. [...] Isso não é um diploma de moral; pois a Imaginação fabuladora é uma potência generosa (criar o outro), e a recusa a "mentir" pode indicar um Narcisismo: tenho apenas, ao que parece, uma imaginação fantasmática (não fabuladora), isto é, narcísica (BARTHES, 2005b, p. 147).

Barthes sabia, evidentemente, que no romance não se trata apenas de "mentira", mas um emprego "peculiar" da linguagem. Dessa forma, esse "eu estou escrevendo um romance" se configura de maneira semelhante ao "eu apaixonado" dos Fragmentos, um personagem que se confunde com seu autor. Esse Romance que ele prepara seria a tentativa da superação de sua própria linguagem ensaística em benefício do romanesco, mas ainda assistimos ao ensaísta que desmonta um texto - no caso, o conjunto de textos e autores diante dos quais ele passeia, para explorar a figura do aprendiz de romancista, similar ao artista amador já descrito anteriormente por ele. O Amador experimenta o puro gozo da prática artística (o seduzido que experimenta a sedução). E Barthes também o compara (e comparase) às falsas ocupações de uma jovem burguesa do século XIX: tocar piano, fazer aquarelas, "sua forma particular de gasto" (2003, p. 65). Um pouco antes, em terceira pessoa, ele também nos confessa a urgência do romanesco em seus textos, cujo motor seria o mesmo desse artista amador (o prazer): 


\section{$300_{\text {critica }}^{\text {criẵ \& }}$}

No que ele escreve, há dois textos. O texto I é reativo, movido por indignações, medos, desaforos interiores, pequenas paranóias, defesas, cenas. O texto II é ativo, movido pelo prazer. Mas ao escrever-se, ao corrigir-se, ao submeter-se à ficção do Estilo, o texto I se torna ele próprio ativo; perde então sua pele reativa, que só subsiste por placas (em minúsculos parênteses). (BARTHES, 2003, p. 55)

Há certo concerto da reação pelo estilo, que apara as arestas do crítico e o deixa em suspenso (entre parênteses). Como se escalonasse diferentes discursos (o crítico, o escritor), no corpo de uma mesma Obra. É o primeiro dos fragmentos indexados (com títulos) em Roland Barthes por Roland Barthes, após o desfile em imagens com observações sobre si. Compagnon (2002) e Comment (1991) acreditavam que Barthes se colocava na posição de Amador para evitar uma afirmação categórica da escrita de um romance em curso: para tentar fugir do possível fracasso (frustramo-nos sempre ao tentar dizer o que se ama) ou, ainda, para buscar a clandestinidade necessária à sua escrita. Ao pronunciar esse "eu" escorregadio que está "escrevendo um Romance", ele não deixa de nos declarar a frustração por antecipação, pois o justapunha à ideia de uma escrita de "simulação, um sonho ou Fantasma" (CARNEIRO, 2007).

Gostamos desse uso da tradução "fantasma" porque evoca, ao mesmo tempo, a fantasia no sentido psicanalítico tal como ele aborda (um desejo de escrever o Romance) quanto o sentido derridiano de uma hantologia particular, i.e.: a sucessão de imagens e Autores que assombram esse que escreve. Era o Fantasma da escritura, "romancinho de bolso" (BARTHES, 2003, p. 101).

$\mathrm{O}$ amador barthesiano não seria uma referência puramente pessoal, mas um "emblema", ou um "personagem conceitual" a serviço de um pensamento crítico: para pensar a literatura, convida seus alunos e leitores a imaginarem esse alguém que escreve. Assim como advoga a subjetividade da análise literária, também se permite explorar a posição subjetiva em que ele insere seu personagem, um personagem de si (que estaria escrevendo um romance).

Ancorado na prática do teatro, do piano, do canto ou, ainda, da pintura, a qual Barthes realizava totalmente ou em parte , o amadorismo foi objeto, a partir daí [1979], de uma teorização que expandiu muito seu alcance: cuidando, mais particularmente nos anos 1970, de desenvolver uma forma de "fisiologia" do amador, Barthes converteu esse amador em uma figura, um personagem conceitual permitindo enunciar o que ele nomeia uma "utopia de civilização", mas também intervir no domínio concreto das formas, do estilo e da técnica, a ponto de fornecer também um ethos eletivo do ensaísta. (CHASSAIN, 2015, nossa tradução) 


\section{Criação \&}

Como aponta Chassain (2015), o desejo de praticar a escritura também faz parte de uma renúncia à divisão de práticas culturais engendradas pela sociedade do consumo, reafirmando, também, o gasto desnecessário (os modos da jovem burguesa em suas atividades inúteis). E se o amador se tornou essa figura da linguagem barthesiana para conduzir um estudo sobre a "preparação do romance", a "reflexividade prática" (CHASSAIN, 2015) que essa figura inspira estão disseminados por toda a obra de Roland Barthes.

Chassain compara o amador (l'amateur) à figura do apaixonado (l'amoureux), ambos guias de análises de discursos (artístico, amoroso), distintos por suas posições diante do mundo (feliz pela prática, infeliz pela espera). Para nós, ambos também são personagens de um universo mitológico com o qual Barthes funda seu pensamento crítico e uma escritura, uma literatura barthesiana que flutua por entre seus ensaios. Esse eu que ele passeia diante dessas figuras, que se apresenta diante de nós como o crítico ou o professor Roland Barthes, RB, "Erbé" também é personagem desse Romance, um ensaio romanesco ou seu "Fantasma da escritura".

Em sua Aula, Barthes pretendia conferir a si essa possibilidade de deslocamento através dos temas e, ao mesmo tempo, não se impor a eles, "eu me misturo e me autorizo em meio aos nomes que considero Autores" (2005b, p. 96). Haveria, porém, uma necessidade de recusar o discurso crítico para simular uma escritura, pois, para melhor compreender a técnica, era preciso experimentá-la, em primeiro grau (COMPAGNON, 2002). Portanto, sem apoiar-se no "meta-discurso da teoria, da metáfora ou leituras críticas dos textos" (KNIGHT, 2002, p. 95, nossa tradução). O Amador é um aprendiz que realiza uma prática alegre de aprendizagem, prazer de ir ao encontro do corpo que lê (um seduzido que pretende seduzir). Como um artista Amador, ele se inicia pela prática da imitação. Ele toma Proust como guia para adentrar as profundezas do Texto. Compara-se com ele: os fragmentos e os ensaios que precederam o Romance, o luto após a morte da Mãe, a busca por elementos que fizessem essa escritura "pegar" (BARTHES, 2004). O luto, por sinal, é vivido como catalisador da escritura, permitindo a sobrevivência do outro no texto. E ele convoca dois incipit importantes, também marcadores de um começo de um percurso após a morte (do Outro): de Dante, ele toma "Nel mezzo del camin de nostra vita" e, de Proust, "Longtemps je me suis couché de bonne heure". Esses começos que retomam um passado não muito distante, perturbado por algo que terminou e clivou a existência.

Quando escrevia sobre a fala do enamorado, em Fragmentos de um discurso amoroso (1977), Barthes afirmou ser este aquele que ocupa sempre a função de esperar o amado e, por transferência, qualquer espera segue o mesmo ritual doloroso do apaixonado: o desconforto inicial, a agitação da angústia, a irritação e o enlutamento. Em sua famosa figura "A Espera", tal ritual foi dividido por ele em cenas, como em uma peça de teatro; no "terceiro ato" da espera, o único ator em cena, o amante, crê finalmente que seu objeto de desejo nunca mais voltará. Estará morto? Essa noção de luto, retomada por Barthes, resume de uma forma 
bem palpável a encenação de uma dor. Ele nos descreve o trabalho de luto d'après Freud (dessa vez, toma Freud como tema de sua prosa): como a criança que chora na ausência da mãe, o enamorado, confrontado com a ausência, precisa manipulála para poder suportá-la. O enamorado romanceia, inventa para si histórias para acalmar-se ou para justificar sua revolta e sua angústia de esperar. Por meio do jogo linguístico, portanto, a dor pela possível "perda" do outro é afastada:

... diz-se que um pequeno instante separa o tempo em que a criança acredita que a mãe está ausente daquele em que acredita que ela já está morta. Manipular a ausência é alongar esse momento, retardar tanto quanto possível o instante em que o outro poderia oscilar secamente da ausência à morte. (BARTHES, 2011b, p. 56)

Outros textos seus apontam essa fragmentação da vida em antes e depois do luto, cuja superação (o trabalho do luto) poderia se dar pela via da escritura, como a conferência "Longtemps je me suis couché de bonne heure" (BARTHES, 1982) em que declarava ser o luto o momento da vida em que nos deparamos com a realidade da morte (o "meio do caminho" dantesco); a morte deixa a vida sem nenhuma qualidade ("inqualificável") em A câmara clara (2009). O "objeto perdido", o outro, não "é mais", "não está mais lá" e a atenção, o carinho, o afeto, o amor que depositávamos nele fica sem destinatário. A referência a Dante também reaparece na "Vita Nova", os fragmentos de um possível romance que Barthes escreveria: como Dante, buscava uma forma nova de escrever; como Dante, ele elege seus guias para adentrar o caminho tortuoso entre inferno e céu do doloroso trabalho de luto que é o desenvolvimento de um a escritura ou estilo novo (CARNEIRO, 2007). Essa flutuação entre o ensaio e o Romance, mesclados aos personagens que ele encena em texto e em aulas, acabaram por acrescentar uma aura romanesca aos escritos por ele deixados. Uma nova camada encantadora, que transformaram esse Autor em um personagem fascinante de sua própria mitologia.

\section{Adorável Roland Barthes}

O Autor, essa categoria burguesa sobre a qual o mesmo Barthes discutiu, é composto, como já lembramos, pelos signos disseminados pelo corpo do texto, aquele ritmo que identificamos como seu. O Autor Roland Barthes distribui-se entre aquele Autor dos Fragmentos ou da Morte do Autor, e também do artista amador que deixou suas inscrições coloridas em cartas e bilhetes a amigos: seus desenhos, igualmente fragmentários, foram objeto da intrigante exposição Roland Barthes Artista Amador (SANTIAGO, 1995), do arquivo pessoal de Romaric Silger Büel - a primeira exposição francesa em torno da figura mais particular de Roland Barthes aconteceria em 2002, no Centre Georges Pompidou. São desenhos semelhantes aos que hoje estão nas capas das edições brasileiras de seus livros (antes, ele nos 


\section{Criação \&}

apresentara seus desenhos "de domingo" em Roland Barthes por Roland Barthes). Talvez sejam as mais belas capas dos livros de Roland Barthes, em que vislumbramos esses seus traços coloridos, a impressão da mão do autor em uma escrita assêmica, o "a grafia por nada..."; "... ou significante sem significado" (BARTHES, 2003, p. 206; 2014). Novamente esse gasto, essa inutilidade de uma prática da jovem burguesa que desenha apenas por prazer, para não se entediar - $e$ sem nenhuma necessidade ou vontade de significar. E são encantadores, esses desenhos, com materiais diversos (aquarela, giz de cera, pastel, nanquim...). No catálogo da exposição, também se transformam em documento: assim como a foto registrando Barthes entre amigos, seus desenhos se tornaram o registro histórico de um Objeto Perdido pessoal, o Roland Barthes que morreu após um convite de um viver-junto a Romaric. No canto de um desenho, lemos um recado de Barthes: "Terça-feira, 16 de março de 1976, às quatorze horas, para fazer companhia à tristeza de Romaric (e talvez alegrá-lo um pouco?)" (SANTIAGO, 1995, p. 46). Dez anos após a exposição (mais de vinte anos após a morte de Barthes), Büel escrevia:

Quando a notícia do acidente que deveria originar a morte de Roland foi de meu conhecimento, a perspectiva de "viver junto" que era a nossa se transformou imediatamente em um verdadeiro luto. Esse luto, estranhamente, eu nunca pude fazer totalmente, como se, mais forte a cada ano que passa, o projeto que Roland tinha formado me aparecesse como um dos raros que poderiam ter tido sentido em minha vida. (BÜEL, 2005, p. 15)

Por esse relato, daquele que talvez tenha amado Barthes persona mais que a maioria de nós, acessamos o detrás das cortinas do Barthes Autor, e participa do conjunto de pistas da imaginada "Vita Nova" que ele esboçava: seria um Romance ou uma vida real? De alguma forma, ele rascunhava uma vida possível após o luto pela morte da mãe, que alteraria fatalmente seu ritmo, seus rumos. Ao entregar esses desenhos ao público da exposição, Romaric também nos emprestou um pouco de sua memória, e nos acrescentou mais camadas de História à construção de nosso personagem Roland Barthes. Também o fizeram os textos e biografias que seus amigos nos legaram, nas quase quatro décadas após a sua morte, em que ainda nos debruçamos sobre seu diário, seus esboços, e quase todo resto de seu corpo foi tornado Obra. Malgré lui? Peut-être, mas o desejamos como nunca, registros desse corpo que escrutamos (velamos?) diferido no tempo, pela via de suas inscrições em escrita, desenhos, texto, fotos e voz.

\section{"A voz, sempre a voz"}

Em uma de suas aulas do curso sobre "O Neutro", Barthes comenta com seus alunos sobre um livro que recebeu de um autor desconhecido, que pouco 


\section{Criação \&}

tempo depois Ihe telefona para perguntar sua opinião. O assédio do escritor, a falta de delicadeza ao exigir uma resposta, Ihe cai como um tormento. Tinha vontade alguma em emitir a mínima impressão, gostaria de permanecer neutro, e essa pressão para definir um gosto ou sentimento era extremamente tortuosa para o crítico. Sua voz, disponível ainda hoje graças a registros dos cursos em hiperlinks da UbuWeb (ROLAND BARTHES, [s. d.]), nos dá acesso a seu enfado meditado, e os risos (e os espirros, a tosse) de sua audiência nos dão os muitos tons de seu humor.

Pelos registros aos quais temos acesso de suas aulas, vislumbramos o autor de "A morte do Autor" apontar seus próprios biografemas enquanto nos apresenta o desenvolvimento de seu pensamento, que parece fragmentário nas notas de aula publicadas posteriormente. Sua voz, as anedotas e os ruídos da sala de aula somam-se ao texto que foi de fato escrito para orientar os cursos. Ouvimos o giz que anota palavras importantes no quadro, uma preocupação didática em explicar e soletrar cada nome ou palavra estrangeira, e entendemos seu descontentamento repetido em algumas aulas em que os alunos sentavam-se apertados, ocupavam os corredores, mesmo se a aula (a mesma voz) era transmitida para uma sala contígua.

Uma verdadeira multidão corre para ouvir as aulas de Barthes no Colégio de França. A sala onde ele fala está repleta duas horas antes da aula. Restam duas "salas sonorizadas", onde se pode ter a experiência de uma aula sem mestre: apenas sua voz, grave, calma, modulada, nunca professoral ou assertiva, mas sempre perpassada por uma leve auto-ironia. As "salas sonorizadas" são o espaço mais adequado para uma aula barthesiana. [...] Os corpos orientados sem constrangimento, nas cadeiras, nos degraus do estrado, nos beirais das janelas. Os olhares se cruzam, passeiam livremente, pela sala decentrada, fitam o céu para além das janelas. (PERRONE-MOISÉS, 2008, p. 87)

Vislumbramos, pelo áudio, seus humores encenados diante de seu público pois toda fala é teatralizada (BARTHES, 2015, p. 10). E sua voz também ecoa em outros textos, como essa elegia da amiga Julia Kristeva:

Esse timbre de uma fragilidade firme confere à sua comunicação imediata, apesar da discrição da conversa, apesar da distância, a força de um contato físico. O homem que se dirige a você entrega a palavra além do sentido. Nada além no tremor desse sem-sentido, desse mais-que-sentido vocal, ele confessa toda sua história e seu corpo. (KRISTEVA, 1982, p. 119, nossa tradução)

A voz de Roland soava ainda aos ouvidos de Kristeva em luto, e permanece nesses registros sonoros como vestígio de um corpo. O que entendemos por voz, a partir do mesmo RB, não é palavra pura, transcendental, divina, mas um corpo em 


\section{$30 \underbrace{}_{\substack{\text { criaçăo \& } \\ \text { critica }}}$}

off, "corpo sonoro que viaja no tempo e no espaço" (HUGLO, 2021, p. 7, nossa tradução) - e, como todo corpo, entretemos com ele sempre uma relação erótica (BARTHES, 2015, p. 186).

A voz de Barthes regia a sala de aula enquanto ele "passeava figuras" diante da audiência distraída por sua voz. Se as notas de cursos chegaram até nós em (tantos) livros póstumos, ao ouvi-lo podemos também descobrir outros biografemas que costuraram seu pensamento (a escrita, a transcrição), seu eu disseminado ao longo das aulas, e que reapareceria na forma de seu corpo, aquele que retorna por meio da escritura. Sua voz faz parte de um tecido de signos de um Autor fascinante, e que se inscreve também como personagem de seu próprio romance - seja Roland Barthes por Roland Barthes ou Câmara clara, para citar dois de seus livros em que ele se permite observar melhor, e em que um eu coincide com aquele descrito pelo autor. Nesses livros, ele se descreve, e nos apresenta suas fotografias, seus desenhos, biografemas e outras inscrições de seu corpo desaparecido, que mantém uma potência vibrante para atrair novos leitores. "Estava fascinada diante de uma voz que me libertava de uma falsa objetividade, porque ali eu podia ver um exercício de fabulação necessário a todo leitor", como escreve a pesquisadora Juliana Bratifisch (BRATFISCH, 2015, p. 11). Isso nos lembra o Proust dialogando com seus Autores:

Nós sentimos muito bem que nossa sapiência começa ali onde termina a do autor, e gostaríamos que ele nos desse respostas, quando tudo o que ele pode fazer é nos dar desejos. E esses desejos, ele só pode acordar em nós ao nos fazer contemplar a beleza suprema para a qual o último esforço de sua arte lhe permitiu atingir. Mas para uma lei singular e aliás providencial da ótica dos espíritos (lei que significa talvez que nós não podemos receber a verdade de ninguém, e que temos que criá-la nós mesmos), o que é o termo de sua sapiência só surge para nós como o começo da nossa, de modo que é o momento em que eles nos dizem tudo o que eles podiam nos dizer que eles fazem nascer em nós o sentimento de que ele não nos disse nada ainda. (PROUST, 2013, nossa tradução)

Aproveitamos esse longo intermezzo iniciado em 2020 (em uma sequência interminável de lutos) para ouvir a voz de Barthes. Permitimo-nos, como os alunos nas "salas sonorizadas", observar janelas enquanto o professor divagava. Além de observar a persistência dessa voz como a de um Fantasma escritor, que ainda assombra nosso texto e nossas pesquisas, essa experiência de escrutar o corpo de sua voz em um momento de distanciamentos veio carregada de "gatilhos": o professor avisava sobre a proibição de não poderem mais fumar em aula, fica inquieto com os alunos apertados entre si. Assim como o corpo dele era testemunha de um tempo terminado - em Comment vivre ensemble, ele explica como as marcas dos tratamentos que passou devido à tuberculose são um registro histórico de uma tuberculose que não existiria mais (após o advento do tratamento por quimioterapia) 


\section{$30 \begin{gathered}\text { criaça o \& } \\ \text { critica }\end{gathered}$}

-, esses registros sonoros são hoje o vestígio de um espaço de aula que passou. Se o cigarro começava a ser interditado nas salas de aula do tempo de Barthes vivo, o tempo que virá não permitirá mais tosses nem espirros em sala de aula, nem alunos que quase se abraçam de tão apertados.

Esse fascínio que compartilhamos entre tantos pesquisadores e leitores barthesianos desdobra-se em textos, conferências, encontros em torno desse autor. Como lembra Bernard Comment (1991, p. 19), sua posição como professor foi de deixar o desejo conduzir o percurso, e sua condução era a de um sedutor. Ele, que observou como todo texto que se quer literário deve paquerar o leitor, também cuidou sua voz e texto para fazer-se adorável, sensual. É de fato bastante curioso como a busca pela escrita de seu romance tornou-se tema de inúmeras pesquisas e textos associados ao luto vivido por ele publicamente, as notas sobre uma "Vita Nova", e sua "preparação do romance" (cito apenas alguns: CARNEIRO, 2007; COMPAGNON, 2002; KNIGHT, 2002; OLIVEIRA, 2020; OLIVEIRA e PINO, 2018). Morto o Autor, deixou tantas pistas que alimentou, inclusive, as bases de um romance policial, em que Laurent Binet posiciona em um ringue um panteão pósestruturalista em disputa por uma maneira de encantar pela linguagem (BINET, 2015). Em nossa hipótese, porém, a "fórmula mágica" ("le septième fonction du langage") foi disseminada ao longo dos textos fragmentários de Barthes: sua metalinguagem autoral desde antes, desde o começo, e o romance fantasmado esteve sempre disperso, pós-moderno, por toda sua Obra. Assim, mesmo se a escritura é a "destruição de toda voz, de toda a origem" (BARTHES, 2004a), pois corporifica um Autor, não a persona e permite o parricídio daquele mesmo que escreve, Barthes soube elaborar elementos de uma mitologia particular em que a voz que escutamos suplementa.

Roland Barthes pode ser visto como um retornante, nos termos de Jacques Derrida (1994): na ausência de seu corpo físico, seu texto e seus registros sonoros permanecem como rumor, assombrando inexoravelmente toda a crítica literária. A sua narrativa pessoal e pública da escrita do romance, envolta pelo luto após a morte de sua mãe, tornaram-se elementos importantes de uma mitologia barthesiana, reencenada nesses inúmeros textos por seus leitores e comentadores. Ao escutarmos seus cursos, vislumbramos o autor de "A morte do Autor" apontar seus próprios biografemas, enquanto nos apresentava o desenvolvimento de seu pensamento, que encontraria na escritura sua elaboração finalizada - a escritura, que também é uma continuação do mesmo corpo que emite a voz, não é transcrição dessa voz, mas o pensamento em si (BARTHES, 2015, p. 13-14). E, na voz, percebemos melhor as piscadelas irônicas e todo o humor de Roland Barthes, misturado a anedotas que não seriam transcritas e aos ruídos da sala de aula. E se a voz permanece inflexível (um registro imutável), seu corpo escrito transcendeu em inúmeros textos íntimos após a morte: além das notas de aulas, os livros Incidentes e Diário de Luto (BARTHES, 2004, 2011a) vivificaram mais que nunca a imagem dele como Autor e todo texto seu como Obra. 


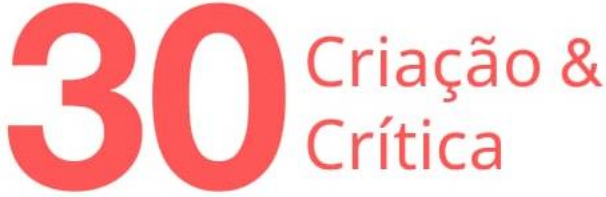

\section{Conclusão}

O Autor - essa categoria historicamente marcada pela lógica burguesa da propriedade - cinde desse corpo plural do sujeito, que do seu corpo emite voz, produz escrita e escritura. A condição de subsistência do Texto ou a sobrevivência do Nome de Autor (sua personalidade) só estaria garantida pelas leituras e releituras futuras, pelo leitor, e é pela disseminação do sujeito-Autor no texto, i.e., a iteração de um estilo, um tom, vícios da escrita, que fazem do Autor um Autor. Esse nome e sua obra só continuam legíveis pela rede de referências sobre a qual se constroem (CARNEIRO, 2009). Ele já criticava há bastante tempo a mitificação do autor, visto como um ser à parte da sociedade, para identificar que o sujeito que constitui o Autor nasce pela escritura. Essa constituição não é transcendente, pois escrever é inscrever-se, ainda depende do corpo.

Assim, em seu curso "A preparação do romance", ele vasculhava gavetas e anotações de escritores para apresentar essa relação entre o biografema e a Obra, em uma observação importante para o pensamento crítico em torno da literatura: mesmo se produzidos por um sujeito, esse sujeito medita, repisa, se separa daquele eu que fala ao produzir a escritura.

Em "De la parole à l'écriture", o crítico Barthes elabora a distinção entre as três práticas que inscrevem o sujeito no mundo: a fala, a escrita que a transpõe de forma mais meditada ("l'écrif") e a escritura ("l'écriture"). Se a primeira ainda prescinde de um corpo, as duas últimas permitem a sobrevivência do sujeito para além dele. A escrita, por sua vez, apaga da palavra tudo que the seria imediato, apaga os sintomas muito evidentes e até mesmo o desejo de ser ouvida: os elementos fáticos são praticamente eliminados no texto, e o Outro a quem me dirijo na fala é obliterado pela escrita. "O corpo, embora sempre presente, deixa de coincidir com a pessoa, ou, melhor dizendo, a personalidade" (BARTHES, 2015, p. 12), e a escrita ainda reclama elementos coesivos hierarquizando ainda mais a linguagem, tentando abranger um interlocutor plural e menos conhecido, em vez daquele Outro visível a quem me dirijo quando falo.

Nós falamos, gravam-nos, secretárias diligentes escutam nossas afirmações, limpam-nas, transcrevem-nas, pontuam-nas, tiram delas um primeiro script que submetem a nós para que limpemos de novo antes de entregar para a publicação, o livro, a eternidade. Não seria essa a "toalete do morto" que acabamos de acompanhar? Nossa fala, nós a embalsamamos, como uma múmia, para fazê-la eterna. Pois é preciso que dure mais que sua voz; é preciso de fato, pela comédia da escritura, se inscrever em algum lugar. (BARTHES, 2015, p. 10, nossa tradução) 


\section{Criação \&}

No entanto, o Barthes que nos escreve que está escrevendo um romance, acaba por se inscrever como uma Figura que observamos caminhar diante de seus textos: em uma mise en abyme, Roland Barthes nos apresenta o luto de RB. E nós, pesquisadores barthesianos, fascinamo-nos em ler e ouvir Roland Barthes, e imaginamos o romance que ele teria nos legado. O sobrevivente, ou o herdeiro é, sem querer, aquele que deve continuar o outro, que recebe essa "missão" de consertar esse mundo, diante da catástrofe (DERRIDA, 2003). Barthes se insere como Autor de um Romance que gostaríamos de continuar a escrever, e "Desde o início de A câmara clara, o Tempo, a Fotografia e a Morte são os fantasmas, talvez os personagens de uma mitologia que Barthes instaura. Marcados em maiúsculas, estão lá, desde o começo, desde o primeiro fragmento" (CARNEIRO, 2007, p. 81). Também o Amador, o Romance e essa persona RB que ele encena são personagens de sua escritura. Ao viver publicamente seu luto, e ao encená-lo em textos, esse Autor convocou seus leitores a enlutarem-se, "tentar ontologizar os restos", presentificá-lo (DERRIDA, 1994, p. 24). Assim, transformou-se nesse espectro de uma hantologia particular, um nome incontornável para a crítica literária, que ainda nos obseda por seus vestígios adoráveis - o timbre de voz, o texto delicado ("descrever a fascinação não pode nunca, no fim das contas, ultrapassar este enunciado: 'estou fascinado'” (BARTHES, 2011b, p. 33)).

Ao mesmo tempo que a escritura destitui aquele que a criou, ela se torna a testemunha da existência de seu autor. A assinatura, que funciona para afirmar a existência dele, pode funcionar também para criar em torno de si as expectativas que possui o leitor ao se deparar com determinado Nome próprio. Com a escrita fragmentária, Barthes talvez pretendesse não se impor à realidade, ser constativo como uma Fotografia. Essa, talvez, fosse a sua utopia de sobreviver na escritura, seu ideal de Romance.

Dessa forma, ao termos o corpo do autor inscrito no Texto, essa sobrevivência é assegurada pelo leitor que, ao revisitar essas obras, atualiza e o inscreve em uma História da Literatura. Barthes tomou Proust como guia, porém não pode reescrever Proust. Em vez do romance longo e denso que the inspirou, ele volta ao fragmento recusado por Proust, retorna no tempo para tentar salvar a literatura em germe, a literatura antes de se tornar o Romance. Assim como buscou na foto de sua mãe criança aquele sorriso (aquele corpo) perdido, a sobrevivência da literatura requer leituras que subam os rios do texto, para que possamos mergulhar também na prática amadora (mesmo se frustrante) de tentar escrever (a)o Autor que amamos.

\section{Referências}

BARTHES, Roland. A câmara clara. Tradução: Julio Castañon Guimarães. Rio de Janeiro: Nova Fronteira, 2009.

A preparação do romance I. Tradução: Leyla Perrone-Moisés. São Paulo: Martins Fontes, 2005a. 


\section{Criação \&}

A preparação do romance II. Tradução: Leyla Perrone-Moisés. São Paulo:

Martins Fontes, 2005b.

. Diário de luto. Tradução: Leyla Perrone-Moisés. São Paulo: Martins Fontes, 2011a.

. Fragmentos de um Discurso Amoroso. Tradução: Hortênsia dos Santos. 16.

ed. Rio de Janeiro: Francisco Alves, 2011b.

Incidentes. Tradução: Mário Laranjeira. São Paulo: Martins Fontes, 2004.

"Isso pega". In: INÉDITOS 2 - CRíTICA. Tradução: Ivone Castilho Benedetti.

[S. I.]: Martins Fontes, 2004. p. 225-229.

Le grain de la voix. Entretiens (1962-1980). Paris: Seuil - Sciences humaines (H.C.), 2015.

"Longtemps je me suis couché de bonne heure". In:

CEuvres

complètes, t III (1974-1980). Paris: Seuil, 2002.

Novos ensaios críticos; seguidos de O grau zero da escritura. Tradução:

Heloysa de Lima Dantas; Anne Arnichand; Álvaro Lorencini. São Paulo: Cultrix, 1974.

Roland Barthes por Roland Barthes. Tradução: Leyla Perrone-Moisés. São

Paulo: Estação Liberdade, 2003.

BINET, Laurent. Quem matou Roland Barthes. Tradução: Rosa Freire Aguiar. São Paulo: Companhia das Letras, 2015.

BRATFISCH, Juliana. "O escritor como expectativa da vida social". Suplemento Pernambuco, Recife, p. 10-13, 2015.

BÜEL, Romaric Sulger. "Viver junto". In: NOVA, Vera Casa; GLENADEL, Paula (org.). Viver com Barthes. Rio de Janeiro: 7Letras, 2005. p. 15-20.

CARNEIRO, M. C. S. R. Luto e escritura em A Câmara Clara de Roland Barthes. 2007. Dissertação (Mestrado em Letras Neolatinas) - Universidade Federal do Rio de Janeiro, Rio de Janeiro, 2007.

"Roland Barthes e a preparação do romance". Lettres Françaises, Araraquara, v. 0, n. 7, p. 161-172, 2009.

CHASSAIN, Adrien. Roland Barthes: "Les pratiques et les valeurs de l'amateur". Fabula-LhT, [s. I.], n. 15, 2015. Disponível em: http://www.fabula.org//ht/15/chassain.html. Acesso em: 13 abr. 2021.

COMMENT, Bernard. Roland Barthes, vers le neutre: Essai. Paris: Christian Bourgois, 1991.

COMPAGNON, Antoine. Le Roman de Roland Barthes. Revue des Sciences Humaines, Paris, n. 267, 2002.

DERRIDA, Jacques. Espectros de Marx. Tradução: Anamaria Skinner. Rio de Janeiro: Relume-Dumará, 1994.

Chaque fois unique, la fin du monde. Paris: Editions Galilée, 2003.

GIORDANO, Alberto. "Vida e obra. Roland Barthes e a escrita do Diário". Outra Travessia, [s. I.], v. 1, n. 21, p. 145-156, 2017. Disponível em: https://doi.org/10.5007/2176-8552.2016n21p145 Acesso em: 01 abr. 2021.

HUGLO, Marie-Pascale. "Présentation: Les imaginaires de la voix". Études Françaises, Montréal, v. 39, n. 1, p. 7-11, 2021. Disponível em: https://doi.org/https://doi.org/10.7202/006737ar. Acesso em: 01 de abril de 2021.

KNIGHT, Diana. Vaines pensées: la Vita Nova de Roland Barthes. Revue des Sciences Humaines, Paris, n. 268, p. 93-107, 2002.

KRISTEVA, Julia. La voix de Barthes. Communications, [s. I.], v. 36, n. 1, p. 119123, 1982. Disponível em: https://doi.org/10.3406/comm.1982.1543

OLIVEIRA, Priscila Pesce Lopes de. Do literário como procedimento: buscas de 


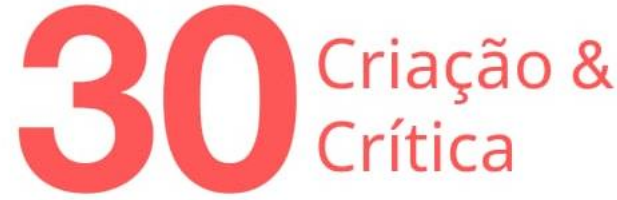

escrita em dois livros de Roland Barthes. 2020. - Universidade Federal do Ceará, Fortaleza, 2020.

OLIVEIRA, Priscila Pesce Lopes de; PINO, Claudia Amigo. "Dois diários, um ensaio e um romance: a presença de "Incidentes" e "Noites de Paris" na escrita narrativa desejada por Roland Barthes". Matraga - Revista do Programa de Pós-Graduação em Letras da UERJ, Rio de Janeiro, v. 25, n. 43, p. 164-192, 2018. Disponível em: https://doi.org/10.12957/matraga.2018.32374. Acesso em: 01 abr. 2021.

PERRONE-MOISÉS, Leyla. Lição de casa. In: BARTHES. Aula. 16. ed. São Paulo: Cultrix, 2008. p. 49-89.

PROUST, M. Delphi Complete Works of Marcel Proust (IIlustrated). [S. I.]: Delphi Classics, 2013.

ROLAND BARTHES. Disponível em: https://www.ubu.com/sound/barthes.html. Acesso em: 1 abr. 2021.

SANTIAGO, Silviano. Roland Barthes: artista amador. Rio de Janeiro: CCBB, 1995.

Recebido em: 15/04/2021 Aceito em: 27/07/2021

Referência eletrônica: CARNEIRO, Maria Clara da Silva Ramos; NASCIMENTO, Lauren Silva. Roland Barthes, adorável: disseminações de uma voz de autor. Criação \& Crítica, n. 30, p., set. 2021. Disponível em: <http://revistas.usp.br/criacaoecritica>. Acesso em: dd $\mathrm{mmm}$. aaaa. 